\title{
Holo-heterococcolithophore life cycles: ecological implications
}

\author{
Lluïsa Cros*, Marta Estrada \\ Institut de Ciències del Mar (CSIC), Passeig Marítim, 37-49, 08003 Barcelona, Spain
}

\begin{abstract}
Many coccolithophores have complex life cycles with haploid and diploid stages bearing structurally different coccolith types (holococcoliths and heterococcoliths, respectively). Laboratory studies suggest that holo- and heterococcolithophores may occupy distinct ecological niches, but the potential ecological implications of the existence of haploid and diploid stages are poorly known. We present here a study of holo- and heterococcolithophore distributions in the Catalano-Balearic Sea, during 2 cruises (MESO-96, from 18 June to 3 July, and FRONTS-96, from 16 to 21 September) that covered 2 intervals of the stratification period of 1996 . We define a holococcolithophore prevalence index (HOLP index), calculated for each coccolithophore-containing sample, as the percent ratio between the number of holococcolithophores and the total number of holo- and heterococcolithophores belonging to families with alternation of holo- and heterococcolithophore life stages (coccolithophores having HOL-HET life cycles; Total_HHLC). In both cruises, the distribution of holo- and heterococcolithophores and the HOLP index indicated a preference of the holococcolithophores for shallower waters and of the heteroccolithophores for deeper layers. This segregation may be linked to a differentiation of ecological niches, with the haploid holococcolithophores occupying the more oligotrophic upper layers and the diploid heterococcolithophores inhabiting relatively rich deeper waters.
\end{abstract}

KEY WORDS: Holococcolithophore prevalence index . Haploid-diploid life cycles . Coccolithophores $\cdot$ NW Mediterranean

Resale or republication not permitted without written consent of the publisher

\section{INTRODUCTION}

Coccolithophores are haptophytes that at some stage of their life cycle possess a cell cover consisting of calcified scales (coccoliths). They are a major component of the oceanic phytoplankton and play an important role in the marine biogeochemistry of carbonate and, therefore, in the carbon cycle (Westbroek et al. 1994, Rost \& Riebesell 2004).

Two structurally different types of coccoliths, heterococcoliths and holococcoliths, are recognizable among the coccolithophores; the heterococcoliths are formed of crystal units of variable shape and size, while the holococcoliths consist of numerous minute $(<0.1 \mu \mathrm{m})$ crystallites (Young et al. 1999). A clear demonstration that holo- and heterococcolithophores could be life- cycle phases of the same species occurred when culture studies by Parke \& Adams (1960) showed that monoclonal strains of the heterococcolithophore CoCcolithus pelagicus gave rise to a holococcolithophore that could be assigned to the genus Crystallolithus. Further evidence concerning coccolithophore life cycles was gathered from work on coastal coccolithophores of the Pleurochrysidaceae and Hymenomonadaceae. These families present an alternation of a motile heterococcolithophore phase and a nonmotile non-calcifying benthic phase (Gayral \& Fresnel 1983, Fresnel 1989, Fresnel \& Billard 1991). Nuclear staining and chromosome counting showed that the heterococcolithophore phase is diploid, while the benthic phase is haploid (Rayns 1962, Fresnel 1994). Other studies indicated that the organic 
body scales of the haploid and diploid phases were different and that the same scale types occurred, respectively in the holo- and heterococcolithophore phases of C. pelagicus (Manton \& Leedale 1969, Gayral \& Fresnel 1983, Fresnel \& Billard 1991), providing support to the hypothesis that coccolith and body scale type could be associated with different ploidy phases (Billard 1994). Later studies using flow-cytometric DNA analysis confirmed this hypothesis and showed that a similar phenomenon occurred with the coccolithophores Calcidiscus leptoporus and Coronosphaera mediterranea (Houdan et al. 2004). The study of coccolithophore life cycles is difficult because only a small number of species are maintained in culture and direct observations of phase changes are rare (Rowson et al. 1986, Noël et al. 2004). Nevertheless, combination coccospheres, which bear both hetero- and holococcoliths and have been interpreted as cells in a life-cycle transition (Geisen et al. 2004), are sporadically recorded in natural samples (e.g. Thomsen et al. 1991, Kleijne 1993, Cros et al. 2000, Cortés \& Bollman 2002, Geisen et al. 2002, Triantaphyllou et al. 2004, Frada et al. 2009), providing an additional source of information. It is now recognized that many families of coccolithophores, including Helicosphaeraceae, Syracosphaeraceae, Rhabdosphaeraceae, Coccolithaceae, Calcidiscaceae, Papposphaeraceae and Pontosphaeraceae (Billard \& Inouye 2004, Frada et al. 2009) have a life cycle with holococcoliths in the haploid phase and heterococcoliths in the diploid phase. The finding that some heterococcolithophores appear to be associated with 2 , or even 3, holococcolithophore 'species', which has been attributed to ecophenotypic variations in the holococcoliths and cryptic or pseudo-cryptic speciation in the diploid phase (Geisen et al. 2002,2004, Saez et al. 2003), complicates even more an understanding of the significance of these life histories.

Coccolithophores tend to occupy ecological environments with an intermediate degree of fertility, midway between the extremes represented by turbulent, nutrient-rich waters, which favour diatom growth, and stratified, nutrient-poor waters, where dinoflagellates and other flagellates tend to dominate (Margalef 1978, Estrada et al. 1999). Within this general trend, coccolithophores present a wide spectrum from r-selection to k-selection (Brand 1994) and their coccolith shape has been related to their nutrient affinity (Young 1994). Field observations indicate that heterococcolithophores such as Emiliania huxleyi, which can form extensive blooms, and Coccolithus pelagicus may be found in environments with a certain degree of nutrient availability (Balch et al.
1992, Cachao \& Moita 2000) while holococcolithophores tended to occur in more oligotrophic waters and appeared to prefer the upper part of the euphotic zone (Kleijne 1993, Cros 2002, Triantaphyllou et al. 2002, Dimiza et al. 2008a). Detailed taxonomic studies of the distribution of holococcolithophores in the field are not common, in part because holococcolithophores degrade easily in water samples and cannot be reliably identified with standard optical microscopy. In a study of samples from weather stations in the western Atlantic, Okada \& McIntyre (1979) found that the holo- and heterococcolithophore stages of $C$. pelagicus were respectively more abundant at the surface and $100 \mathrm{~m}$ of depth, and that the relative proportion between both forms changed markedly along a seasonal cycle. Based on samples of the northern north Atlantic, Balestra et al. (2004) reported also that the holococcolithophore phase of $C$. pelagicus tended to occur at shallower levels of the water column.

Houdan et al. (2006) used laboratory experiments with cultures to show that the haploid and diploid stages of Coccolithus braarudii and Calcidiscus leptoporus corresponded to different ecological strategies, with the haploid phase, flagellated and capable of mixotrophy, exploiting a more oligotrophic niche than the diploid phase, which grew faster in nutrientrich media. However, the potential ecological implications of the existence of haploid and diploid stages are poorly known and there is a need of comparative studies of holo- and heterococcolithophore distributions in natural ecosystems.

In this work, we present a study of holo- and heterococcolithophore distributions in the CatalanoBalearic Sea during 2 different periods of the year, emphasizing the comparison between holo- and heterococcolithophore stages of the same species, and discuss the ecological interpretation of our findings. Because of the spotty distribution or lack of the holoor heterococcolithophore phase cells of many of the species, we propose a numerical index (HOLP index) as a tool to evaluate the general prevalence of the holococcolithophore phase in the water column.

\section{MATERIALS AND METHODS}

\section{Sea water samples}

The studied samples were collected during the cruises MESO-96 and FRONTS-96, carried out in the Catalano-Balearic Sea (NW Mediterranean) on board the RV 'García del Cid', from 18 June to 3 July 1996 
and from 16 to 21 September 1996, respectively. Fig. 1 shows the positions of the sampled stations and Table 1 details the geographic positions of the stations and the date and time when they were visited.

At each station, vertical profiles of temperature, salinity and fluorescence were obtained with a Neil Brown Mark III CTD probe. Water samples were obtained at selected depths between 5 and, usually, $100 \mathrm{~m}$ of depth (one sample was taken from $160 \mathrm{~m}$ ) using a rosette with Niskin bottles, attached to the CTD system. Chlorophyll a (chl a) concentration was determined by measuring the fluorescence of acetonic extracts (Yentsch \& Menzel 1963) with a Turner Designs fluorometer. Analyzed chl a concentrations were used to calibrate the fluorescence readings of the CTD system. For coccolithophore enumeration, about $200 \mathrm{~cm}^{3}$ of sea water were filtered, using a vacuum pump, onto a polycarbonate membrane filter of $0.8 \mu \mathrm{m}$ pore size and $25 \mathrm{~mm}$ diameter, placed on top of a cellulose ester filter of $3 \mu \mathrm{m}$ pore size. Salt was removed by washing the filters with about 1 to $2 \mathrm{~cm}^{3}$ of bottled drinking

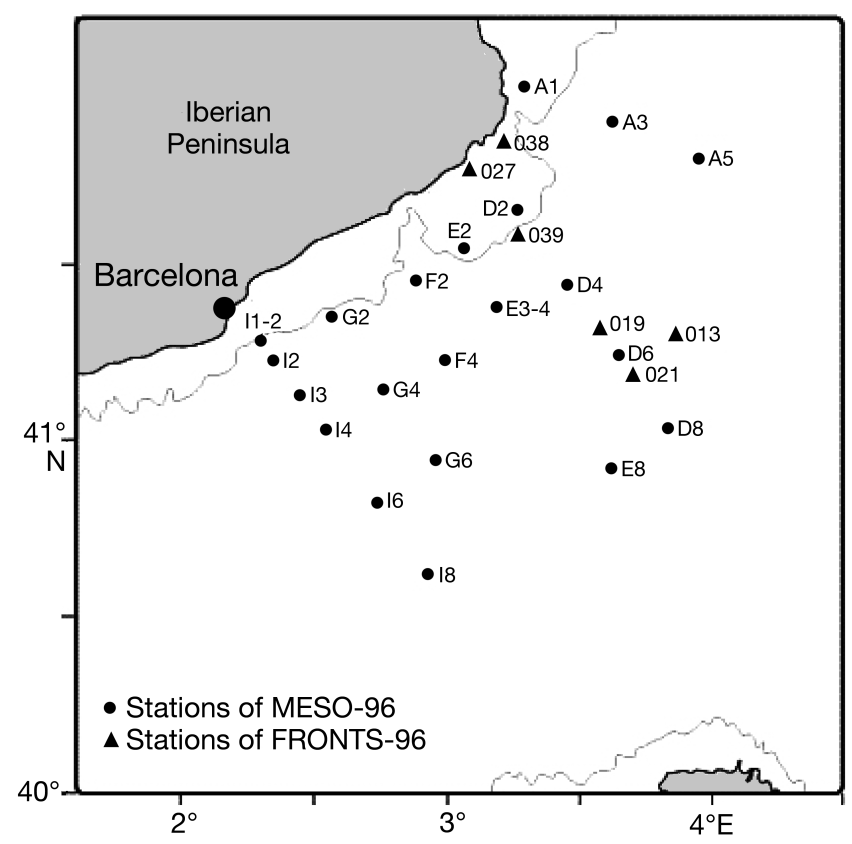

Fig. 1. Position of the stations sampled in the cruises MESO96 and FRONTS-96

Table 1. Geographic position, date and time of visit of the sampled stations

\begin{tabular}{|c|c|c|c|c|c|}
\hline Station & Date & Time (GMT) & Latitude (N) & Longitude (E) & Sampling depth (m) \\
\hline \multicolumn{6}{|c|}{ Cruise MESO-96 } \\
\hline A1 & 18-6-1996 & $22: 39 \mathrm{~h}$ & $42^{\circ} 00.0^{\prime}$ & $3^{\circ} 17.3^{\prime}$ & $5,40,70,100$ \\
\hline A3 & 19-6-1996 & $01: 38 \mathrm{~h}$ & $41^{\circ} 54.0^{\prime}$ & $3^{\circ} 37.1^{\prime}$ & $5,40,70,100$ \\
\hline A5 & 19-6-1996 & $11: 57 \mathrm{~h}$ & $41^{\circ} 48.0^{\prime}$ & $3^{\circ} 56.9^{\prime}$ & $5,40,70,100$ \\
\hline D2 & 21-6-1996 & $06: 36 \mathrm{~h}$ & $41^{\circ} 38.9^{\prime}$ & $3^{\circ} 15.0^{\prime}$ & $5,40,70,100$ \\
\hline D4 & 21-6-1996 & $03: 31 \mathrm{~h}$ & $41^{\circ} 26.6^{\prime}$ & $3^{\circ} 26.5^{\prime}$ & $5,40,70,100$ \\
\hline D6 & 20-6-1996 & $23: 55 \mathrm{~h}$ & $41^{\circ} 14.3^{\prime}$ & $3^{\circ} 38.0^{\prime}$ & $5,40,70,100$ \\
\hline D8 & 20-6-1996 & $20: 34 \mathrm{~h}$ & $41^{\circ} 02.0^{\prime}$ & $3^{\circ} 49.5^{\prime}$ & $5,40,70,100$ \\
\hline $\mathrm{E} 2$ & 30-6-1996 & $12: 45 \mathrm{~h}$ & $41^{\circ} 33.0^{\prime}$ & $3^{\circ} 03.0^{\prime}$ & $5,40,70,100$ \\
\hline E3-4 & 01-7-1996 & $08: 12 \mathrm{~h}$ & $41^{\circ} 23.0^{\prime}$ & $3^{\circ} 10.2^{\prime}$ & $5,40,70,100$ \\
\hline E8 & 02-7-1996 & $08: 30 \mathrm{~h}$ & $40^{\circ} 55.1^{\prime}$ & $3^{\circ} 36.6^{\prime}$ & $5,70,100$ \\
\hline $\mathrm{F} 2$ & 23-6-1996 & $23: 58 \mathrm{~h}$ & $41^{\circ} 27.2^{\prime}$ & $2^{\circ} 52.0^{\prime}$ & $5,40,70,100$ \\
\hline $\mathrm{F} 4$ & 24-6-1996 & $04: 12 \mathrm{~h}$ & $41^{\circ} 13.7^{\prime}$ & $2^{\circ} 59.7^{\prime}$ & $5,40,70,100$ \\
\hline $\mathrm{G} 2$ & 24-6-1996 & $09: 15 \mathrm{~h}$ & $41^{\circ} 20.9^{\prime}$ & $2^{\circ} 33.7^{\prime}$ & $5,20,40,50,70,100$ \\
\hline G4 & 24-6-1996 & $17: 27 \mathrm{~h}$ & $41^{\circ} 08.6^{\prime}$ & $2^{\circ} 45.2^{\prime}$ & $5,40,70,100$ \\
\hline G6 & 25-6-1996 & 09:43 h & $40^{\circ} 56.3^{\prime}$ & $2^{\circ} 56.7^{\prime}$ & $5,40,70,100$ \\
\hline $\mathrm{I} 1-2$ & 29-6-1996 & $12: 05 \mathrm{~h}$ & $41^{\circ} 17.0^{\prime}$ & $2^{\circ} 17.8^{\prime}$ & $5,40,70,100$ \\
\hline $\mathrm{I} 2$ & $24-6-1996$ & $23: 00 \mathrm{~h}$ & $41^{\circ} 13.9^{\prime}$ & $2^{\circ} 20.7^{\prime}$ & $5,40,70,100$ \\
\hline I3 & 28-6-1996 & $08: 06 \mathrm{~h}$ & $41^{\circ} 07.7^{\prime}$ & $2^{\circ} 26.5^{\prime}$ & $5,40,70,100$ \\
\hline $\mathrm{I} 4$ & 25-6-1996 & 02:09 h & $41^{\circ} 01.6^{\prime}$ & $2^{\circ} 32.2^{\prime}$ & $5,40,70,100$ \\
\hline I6 & $25-6-1996$ & $05: 27 \mathrm{~h}$ & $40^{\circ} 49.3^{\prime}$ & $2^{\circ} 43.7^{\prime}$ & $5,40,70,100$ \\
\hline I8 & $27-6-1996$ & $10: 13 \mathrm{~h}$ & $40^{\circ} 37.0^{\prime}$ & $2^{\circ} 55.2^{\prime}$ & $5,40,70,100$ \\
\hline \multicolumn{6}{|c|}{ Cruise FRONTS-96 } \\
\hline 013 & 16-9-1996 & $03: 12 \mathrm{~h}$ & $41^{\circ} 17.8^{\prime}$ & $3^{\circ} 51.2^{\prime}$ & $10,30,60,66,75,90$ \\
\hline 019 & $17-9-1996$ & $10: 55 \mathrm{~h}$ & $41^{\circ} 19.3^{\prime}$ & $3^{\circ} 33.5^{\prime}$ & $5,30,57,100$ \\
\hline 021 & $17-9-1996$ & $11: 55 \mathrm{~h}$ & $41^{\circ} 11.7^{\prime}$ & $3^{\circ} 41.6^{\prime}$ & $20,30,50,68,90$ \\
\hline 027 & 18-9-1996 & $10: 39 \mathrm{~h}$ & $41^{\circ} 46.7^{\prime}$ & $3^{\circ} 03.9^{\prime}$ & $5,10,20,30,45$ \\
\hline 038 & 20-9-1996 & $15: 23 \mathrm{~h}$ & $41^{\circ} 51.0^{\prime}$ & $3^{\circ} 12.0^{\prime}$ & $15,35,45,60$ \\
\hline 039 & 21-9-1996 & $08: 51 \mathrm{~h}$ & $41^{\circ} 35.3^{\prime}$ & $3^{\circ} 15.8^{\prime}$ & $10,30,40,50,70,160$ \\
\hline
\end{tabular}


water. The filters were air dried and stored under partial vacuum in hermetically sealed boxes until preparation for the scanning electron microscope (SEM).

\section{Analytical SEM methodology}

A part of the membrane filter was placed on a SEM stub and coated with a film (of about $150 \AA$ ) of gold or gold-palladium, to avoid electric charges; the sputter coater used was a Polaron SC-500. The examination and counting of the specimens as well as the microphotographs were made with a Hitachi S-570 scanning electron microscope. Detailed explanations of the SEM methodologies can be found in Cros \& Fortuño (2002).

\section{Holococcolithophore prevalence index (HOLP index)}

Let Total_HHLC be the total number of coccolithophores (including both holo- and heterococcolithophores) belonging to families with recognized Holococcolithophore-Heterococcolithophore (HolHet) Life Cycles (Calcidiscaceae, Coccolithaceae, Helicosphaeraceae, Papposphaeraceae, Pontosphaeraceae, Rhabdosphaeraceae and Syracosphaeraceae).

The index of holococcolithophore prevalence, HOLP, is defined for each coccolithophore-containing sample, when total HHLC > 0, as:

$$
\text { HOLP }=100 * \frac{\text { Total Holococcolithophores }}{\text { Total_HHLC }}
$$

If $\mathrm{HHLC}=0$, then HOLP $=0$

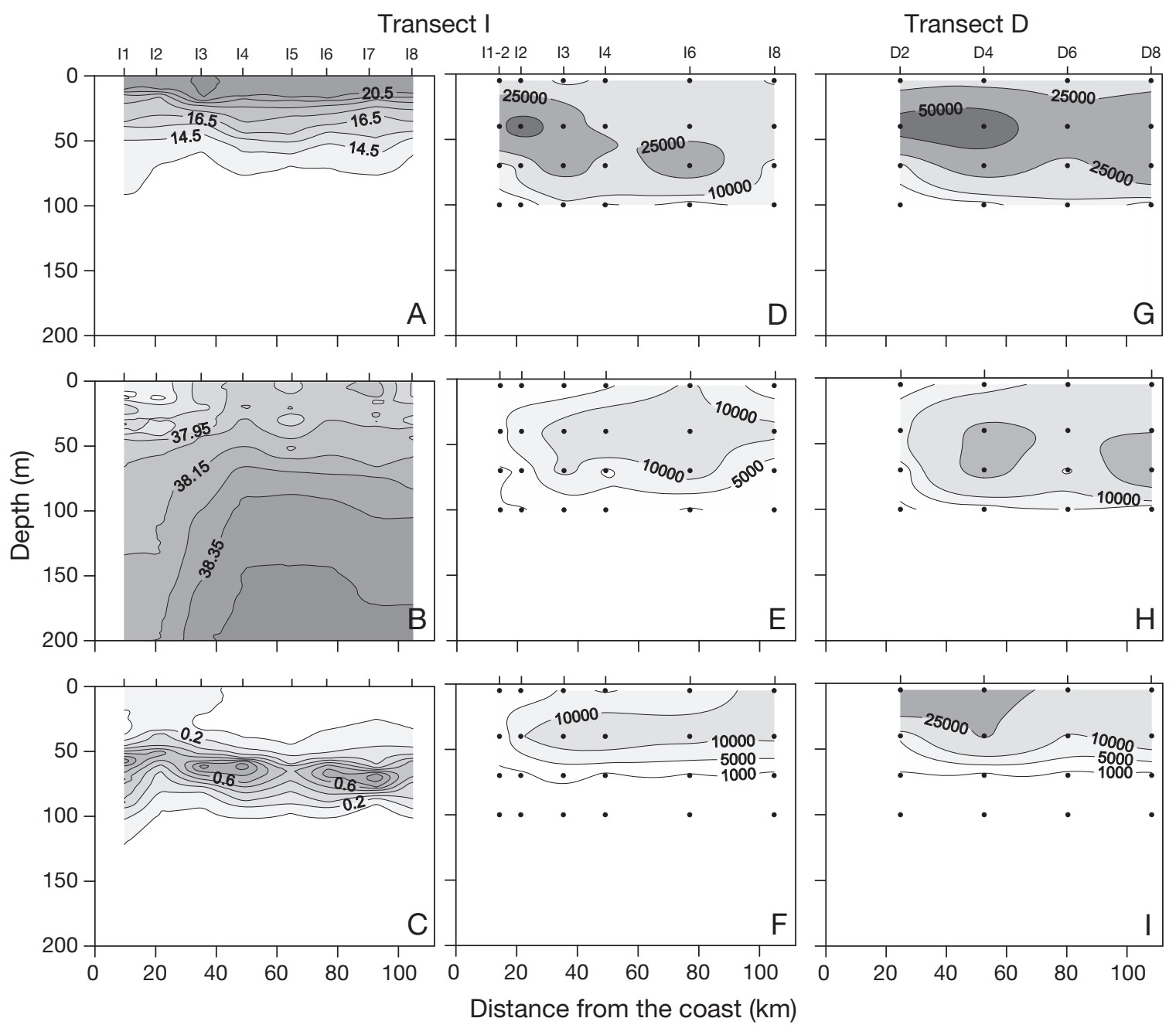

Fig. 2. Cruise MESO-96: Distribution of (A) temperature, (B) salinity, (C) chl a concentration in transect I. In (D) and (G), respectively: Distribution of total heterococcolithophores (cells $\mathrm{l}^{-1}$ ) in transects I and D. In (E) and (H), respectively: Distribution of heterococcolithophores (cells ${ }^{-1}$ ) from families with holococcolithophore-heterococcolithophore life cycles (Het_ HHLC) in transects I and D. In (F) and (I), respectively: Distribution of total holococcolithophores (cells $\mathrm{l}^{-1}$ ) in transects I and D 

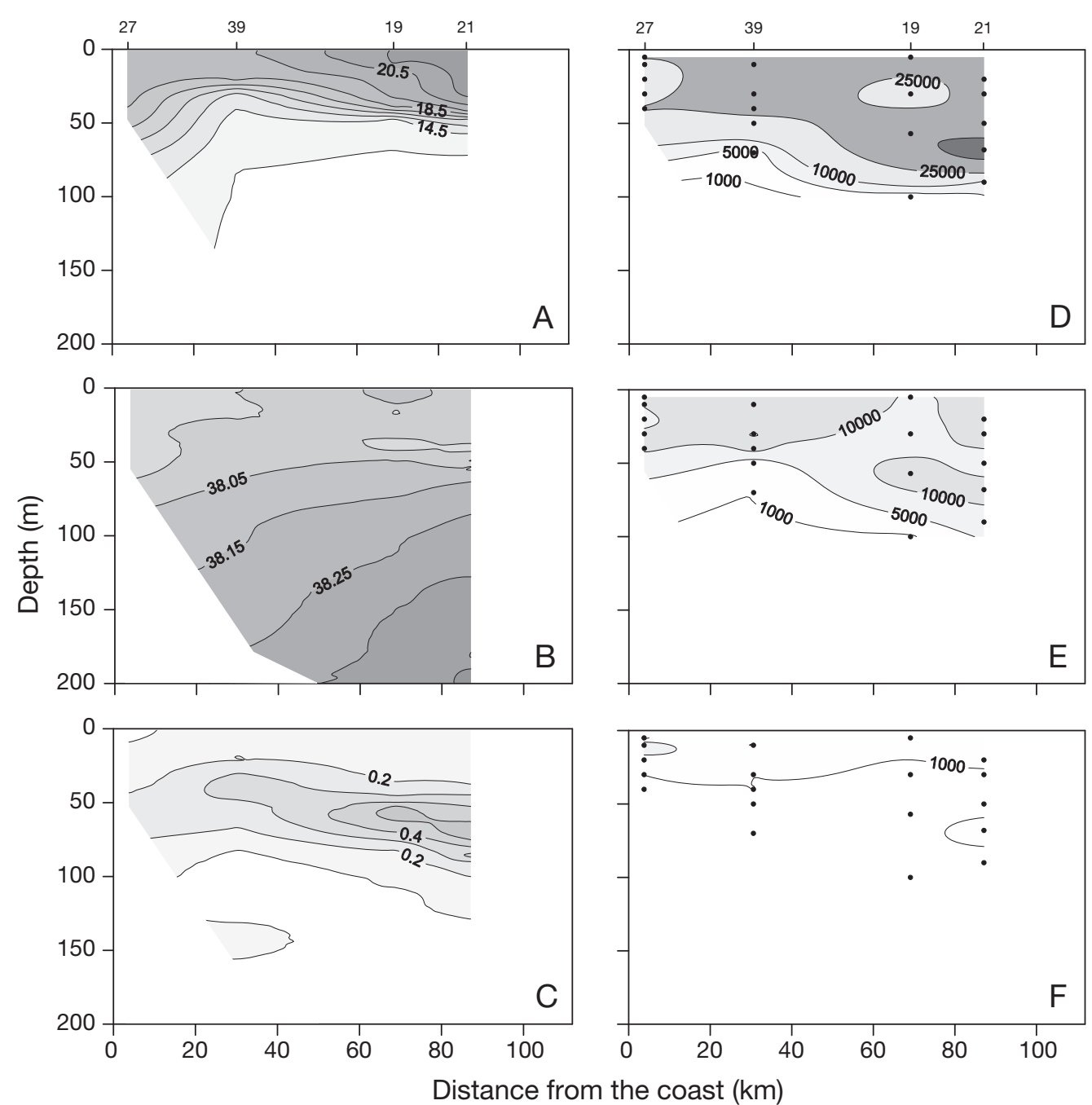

Fig. 3. Cruise FRONTS-96: Distribution of (A) temperature, (B) salinity, (C) chl a concentration, (D) total heterococcolithophores (cells $\left.\mathrm{l}^{-1}\right)$, (E) heterococcolithophores (cells $\mathrm{l}^{-1}$ ) from families with holococcolithophore-heterococcolithophore life cycles, (F) holococcolithophores

The values are given as the means and the standard errors of the subsets of HOLP values belonging to the depth intervals (in m): 5-25, 26-50, 51-80, 81-160 (see Fig. 7). The corresponding points are located at the mean depth of the observations included in each subset.

\section{RESULTS}

\section{Hydrographic features during the MESO-96 and FRONTS-96 cruises}

As can be seen in Figs. 2 \& 3, during both cruises there was marked stratification of the water column, with a sharper thermocline in June and July (MESO96). The signature of the Catalan Front was apparent in the salinity distributions, approximately 40 to
$50 \mathrm{~km}$ offshore of the continental coast. At the surface, chl a concentrations ranged between 0.1 and $0.2 \mathrm{mg} \mathrm{m}^{-3}$ at most stations of FRONTS-96, but did not exceed $0.1 \mathrm{mg} \mathrm{m}^{-3}$ offshore of the Catalan Front in MESO-96. The deep chl a maximum (DCM), which occurred in both cruises at depths of 50 to $70 \mathrm{~m}$ (Figs. 2C \& 3C), was more marked in MESO-96, with chl a concentrations reaching up to $1.37 \mathrm{mg} \mathrm{m}^{-3}$, in comparison with only $0.60 \mathrm{mg} \mathrm{m}^{-3}$ in FRONTS-96.

\section{Hetero- and holococcolithophore diversity and distribution}

The total number of heterococcolithophore and holococcolithophore taxa was, respectively, 56 and 33 in MESO-96, and 47 and 18 in FRONTS-96. Holococ- 
Table 2. Relative abundance of heterococcolithophores and holococcolithophores represented in MESO-96 cruise: heterococcolithophore (HET)-holococcolithophore (HOL) life cycle pairs, most abundant hetero- and holococcolithophores either without a recognized pair or with a pair not found in our samples, and most abundant heterococcolithophores without a HET-HOL life cycle

\begin{tabular}{|c|c|c|c|}
\hline $\begin{array}{l}\text { HET-HOL life cycle pairs } \\
\text { Heterococcolithophores }\end{array}$ & $\%$ & Holococcolithophores & $\%$ \\
\hline Acanthoica quattrospina ${ }^{\mathrm{a}}$ & 0.52 & A. quattrospina HOL, formerly Sphaerocalyptra sp. ${ }^{\text {a }}$ & 0.21 \\
\hline Algirosphaera robusta & 0.52 & Sphaerocalyptra quadridentata ${ }^{\mathrm{b}}$ & 0.52 \\
\hline Rhabdosphaera clavigera & 2.97 & Sphaerocalyptra quadridentata ${ }^{\mathrm{b}}$ & \\
\hline Coronosphaera mediterranea ${ }^{\mathrm{c}}$ & 0.06 & C. mediterranea HOL, formerly Calyptrolithina wettsteinii & 1.31 \\
\hline Coronosphaera mediterranea ${ }^{\mathrm{c}}$ & & C. mediterranea HOL, formerly Zygosphaera hellenica & 0.15 \\
\hline Helicosphaera carteri ${ }^{\mathrm{C}}$ & 3.18 & H. carteri HOL, formerly Syracolithus catilliferus & 2.29 \\
\hline Helicosphaera carteri ${ }^{\mathrm{C}}$ & & H. carteri HOL, formerly Syracolithus confusus & 0.42 \\
\hline Syracosphaera anthos ${ }^{\mathrm{a}}$ & 0.21 & S. anthos HOL, formerly Periphyllophora mirabilis ${ }^{\mathrm{a}}$ & 0.33 \\
\hline Syracosphaera amoena ${ }^{\mathrm{C}}$ & 0.17 & S. amoena HOL, formerly Corisphaera sp. type A of Kleijne & 0.19 \\
\hline Syracosphaera amoena ${ }^{\mathrm{C}}$ & & S. amoena HOL formerly Zygosphaera bannockii & 0.02 \\
\hline Syracosphaera delicata ${ }^{a}$ & 0.02 & S. delicata HOL, formerly Corisphaera sp. type B of Kleijne & 0.10 \\
\hline Syracosphaera didyma ${ }^{\mathrm{d}}$ & 0.42 & Homozygosphaera arethusae $\mathrm{d}^{\mathrm{d}}$ & 2.56 \\
\hline Syracosphaera halldalii ${ }^{\mathrm{e}}$ & 1.35 & S. halldalii HOL, formerly Calyptrolithina divergens var. tuberosa & 0.17 \\
\hline Syracosphaera histrica ${ }^{\mathrm{d}}$ & 0.23 & Calyptrolithophora papillifera ${ }^{\mathrm{d}}$ & 1.68 \\
\hline Syracosphaera molischii ${ }^{\mathrm{d}}$ & 4.18 & Anthosphaera fragaria ${ }^{\mathrm{d}}$ & 0.69 \\
\hline Syracosphaera nana ${ }^{\mathrm{a}}$ & 0.29 & S. nana $\mathrm{HOL}^{\mathrm{a}}$ & 0.19 \\
\hline Syracosphaera nodosa ${ }^{\mathrm{d}}$ & 0.29 & Helladosphaera cornifera ${ }^{\mathrm{d}}$ & 5.65 \\
\hline Syracosphaera pulchra ${ }^{a}$ & 0.98 & S. pulchra HOL, formerly Calyptrosphaera oblonga ${ }^{\mathrm{a}}$ & 0.10 \\
\hline SUBTOTAL & 15.39 & SUBTOTAL & 16.58 \\
\hline \multicolumn{2}{|c|}{ Most abundant HETs without HOL pair } & \multicolumn{2}{|l|}{ Most abundant HOLs without HET pair } \\
\hline Rhabdosphaera xifos & 5.15 & Holococcolithophora heimdaleae & 2.64 \\
\hline Umbellosphaera tenuis & 2.74 & Sphaerocalyptra cf. adenensis & 2.10 \\
\hline SUBTOTAL & 7.89 & SUBTOTAL & 4.74 \\
\hline \multicolumn{4}{|c|}{ Most abundant HETs without HET-HOL life cycle } \\
\hline Emiliania huxleyi & 31.81 & & \\
\hline Gephyrocapsa ericsonii & 6.54 & & \\
\hline SUBTOTAL & 38.35 & SUM OF SUBTOTALS & 82.95 \\
\hline \multicolumn{4}{|c|}{$\begin{array}{l}{ }^{\text {}} \text { Holococcolithophore that has been related to } 2 \text { heterococcolithophores (Cros \& Fortuño 2002,Triantaphyllou \& Dimiza } \\
\text { 2003) }\end{array}$} \\
\hline \multicolumn{4}{|c|}{$\begin{array}{l}\text { 'Heterococcolithophore that has been related to } 2 \text { or more holococcolithophores (Cros et al. 2000, Geisen et al. 2002, } \\
\text { Dimiza et al. 2008b) }\end{array}$} \\
\hline \multicolumn{4}{|c|}{${ }^{\mathrm{d}}$ Pair subject to confirmation (Cros et al. 2000) } \\
\hline eHET-HOL pair established in ? & 1 & 1 & \\
\hline
\end{tabular}

colithophores represented $29.8 \%$ of the coccospheres in MESO-96 and 4.8\% in FRONTS-96. In some cases, one heteroccolithophore (or holococcolithophore) morphotype was recorded in association with, respectively, 2 or more holococcolithophore (or heterococcolithophore) morphotypes; however, for simplicity, we will refer to these associations as 'pairs'. Tables $2 \& 3$ show the relative abundance of the hetero- and holococcolithophores represented in the samples. The most abundant species in both cruises was Emiliania huxleyi, which does not have a heteroholococcolithophore life cycle (Tables $2 \& 3$ ). Detailed abundance data for the taxa considered here can be found in Tables S1 \& S2 in the Supplement at www.int-res.com/articles/suppl/m492p057_supp.xls.
The distribution of total heterococcolithophores, heterococcolithophores belonging to Hol-Het life cycle families (abbreviated as Het_HHLC) and holococcolithophores is represented in Figs. 2 \& 3. The distributions of some hetero-holococcolithophore pairs of each cruise are shown in Figs. 4 to 6. The choice of these examples took into account, first, that the association was a well-established one, with only one heterococcolithophore morphotype involved, and second, that the heterococcolithophore or both phases presented relatively high abundances. The concentration of total heterococcolithophores and Het-HHLC was broadly similar in the 2 cruises, while that of holococcolithophores was markedly lower in FRONTS-96. Population 
Table 3. Relative abundance of heterococcolithophores and holococcolithophores represented in FRONTS-96 cruise: heterococcolitthophore (HET)-holococcolithophore (HOL) life cycle pairs, most abundant hetero- and holococcolithophores either without a recognized pair or with a pair not found in our samples, and most abundant heterococcolithophores without a HET-HOL life cycle

\begin{tabular}{|c|c|c|c|}
\hline $\begin{array}{l}\text { HET-HOL life cycle pairs } \\
\text { Heterococcolithophores }\end{array}$ & $\%$ & Holococcolithophores & $\%$ \\
\hline Coronosphaera mediterranea ${ }^{\mathrm{c}}$ & 0.31 & C. mediterranea HOL, formerly Calyptrolithina wettsteinii ${ }^{\mathrm{C}}$ & 0.19 \\
\hline Helicosphaera carteri ${ }^{\mathrm{a}}$ & 0.56 & H. carteri HOL, formerly Syracolithus catilliferus ${ }^{\mathrm{a}}$ & 0.06 \\
\hline Scyphosphaera apsteinii ${ }^{\mathrm{b}}$ & 0.06 & S. apsteinii HOL, formerly Syracolithus schilleri ${ }^{\mathrm{b}}$ & 0.13 \\
\hline Syracosphaera anthos ${ }^{\mathrm{a}}$ & 0.31 & S. anthos HOL, formerly Periphyllophora mirabilis ${ }^{\mathrm{a}}$ & 0.19 \\
\hline Syracosphaera amoena ${ }^{\mathrm{C}}$ & 0.06 & S. amoena HOL, formerly Corisphaera sp. type A of Kleijne ${ }^{\mathrm{c}}$ & 0.06 \\
\hline Syracosphaera didyma ${ }^{\mathrm{d}}$ & 0.44 & Homozygosphaera arethusae ${ }^{\mathrm{d}}$ & 0.88 \\
\hline Syracosphaera histrica ${ }^{\mathrm{d}}$ & 1.00 & Calyptrolithophora papillifera ${ }^{\mathrm{d}}$ & 0.19 \\
\hline Syracosphaera molischii ${ }^{\mathrm{d}}$ & 1.69 & Anthosphaera fragaria ${ }^{\mathrm{d}}$ & 0.31 \\
\hline Syracosphaera nodosa ${ }^{\mathrm{d}}$ & 0.25 & Helladosphaera cornifera ${ }^{\mathrm{d}}$ & 0.38 \\
\hline SUBTOTAL & 4.68 & SUBTOTAL & 2.39 \\
\hline \multicolumn{2}{|c|}{ Most abundant HETs without HOL pair } & \multicolumn{2}{|l|}{ Most abundant HOLs without HET pair } \\
\hline Rhabdosphaera clavigera & 7.27 & Holococcolithophora sphaeroidea & 0.38 \\
\hline Syracosphaera ossa & 3.01 & Corisphaera spp. & 1.13 \\
\hline Syracosphaera pulchra & 1.76 & SUBTOTAL & 1.51 \\
\hline Umbellosphaera tenuis & 7.59 & & \\
\hline SUBTOTAL & 19.63 & & \\
\hline \multicolumn{4}{|c|}{ Most abundant HETs without HET-HOL life cycle } \\
\hline Emiliania huxleyi & 45.45 & & \\
\hline Gephyrocapsa ericsonii & 13.29 & & \\
\hline SUBTOTAL & 58.74 & SUM OF SUBTOTALS & 86.95 \\
\hline \multicolumn{4}{|c|}{${ }^{a}$ HET-HOL pair established in Cros et al. (2000) } \\
\hline \multicolumn{4}{|c|}{${ }^{\mathrm{b}}$ HET-HOL pair established in Frada et al. (2009) } \\
\hline \multicolumn{4}{|c|}{ 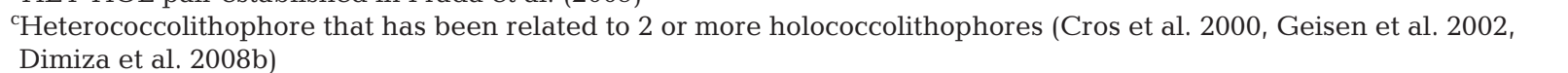 } \\
\hline \multicolumn{4}{|c|}{${ }^{\mathrm{d}}$ Pair subjected to confirmation (Cros et al. 2000) } \\
\hline
\end{tabular}

densities of total heterococcolithophores and Het_HHLC tended to present subsurface maxima in June (MESO-96) and to be highest in the near surface layers in September (FRONTS-96). Emiliania huxleyi, which dominated the heterococcolithophore community, was generally more abundant around 40 to $60 \mathrm{~m}$ of depth (data not shown). As can be seen in Figs. 2F,I \& 3F, the holococcolithophores were found in the upper meters of the water column, while the heterococcolithophores, although sometimes present also at the surface, tended to occupy deeper waters and to present deeper population maxima. The recorded heteroand holococcolithophore life stages (see examples in Figs. 4 to 6) reproduced this pattern, although their distributions were often patchy. The preference of holococcolithophores for shallower depths than heterococcolithophores was reflected in the vertical distribution of the HOLP index, which decreased markedly with depth in the 2 cruises (Fig. 7), although its surface values in June were more than 3 times larger than in September.

\section{DISCUSSION}

The ecological characteristics of the open NW Mediterranean marine ecosystem are intimately linked to the seasonal changes in environmental forcing and the annual cycles of mixing and stratification of the water column. Typically, phytoplankton biomass increases in late winter or spring, after winter mixing injects nutrients into the euphotic zone, and decreases towards the summer, when nutrients become depleted in the upper mixed layer. During the stratification period, maximum chl a concentrations, generally reflecting both higher phytoplankton biomass and enhanced chl a content per cell, are found at the bottom of the euphotic zone. In autumn, weakening of the pycnocline may produce a second phytoplankton peak (D'Ortenzio \& Ribera d'Alcalà 2009). In the area of study, inshore of the Catalan Front, the winter-spring bloom is dominated by diatoms, but offshore of this front the dominant phytoplankton forms are haptophytes and dinoflagellates. As stratification increases, the contribution of these 


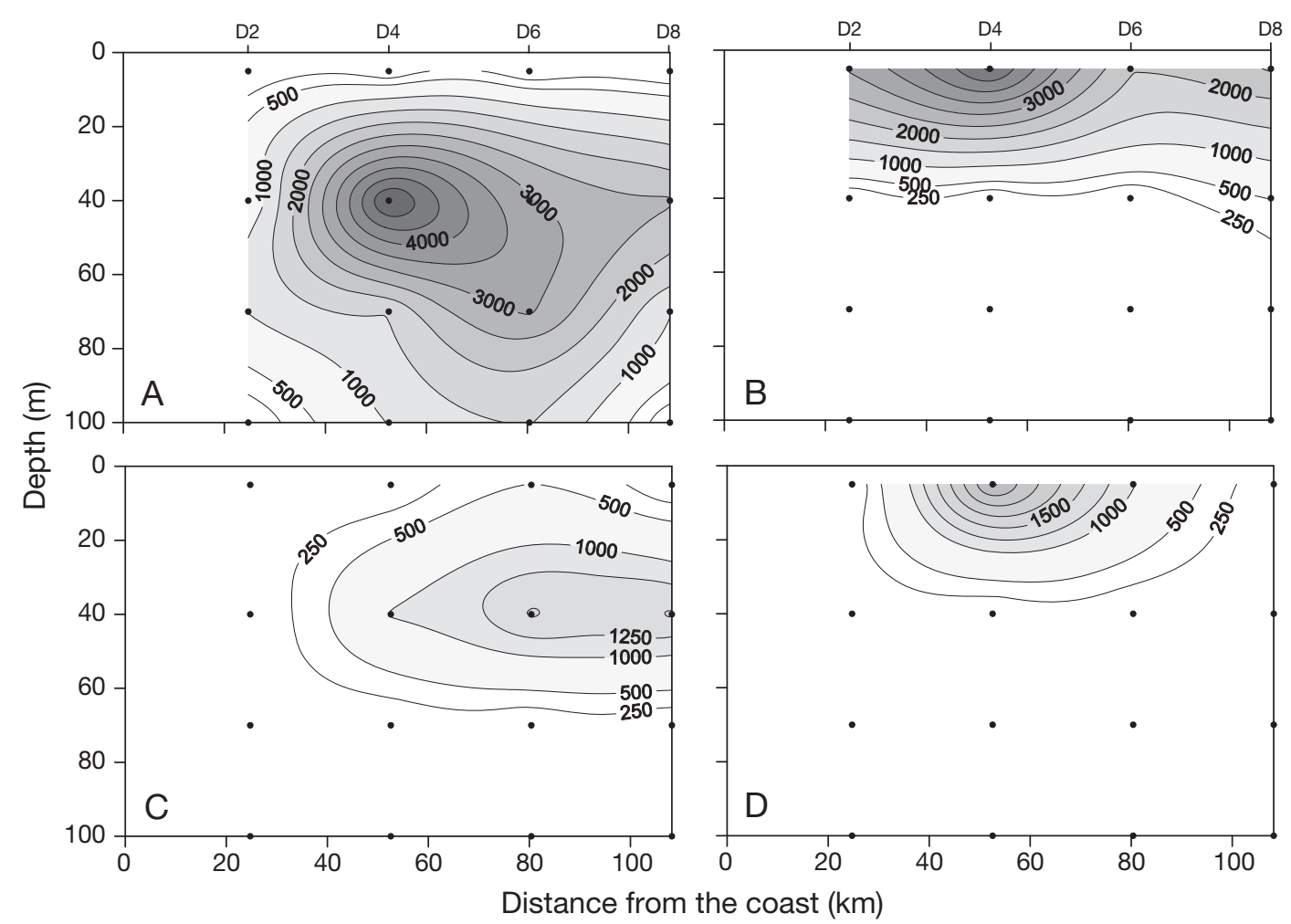

Fig. 4. Distribution of representative hetero-holococcolithophore pairs in transect D of MESO-96 (values in cells $\mathrm{l}^{-1}$ ). In (A) and (B), respectively: Helicosphaera carteri HET and H. carteri HOL, formerly Syracolithus catilliferus. In (C) and (D), respectively: Syracosphaera halldalii HET and S. halldalii HOL, formerly Calyptrolithina divergens var. tuberosa

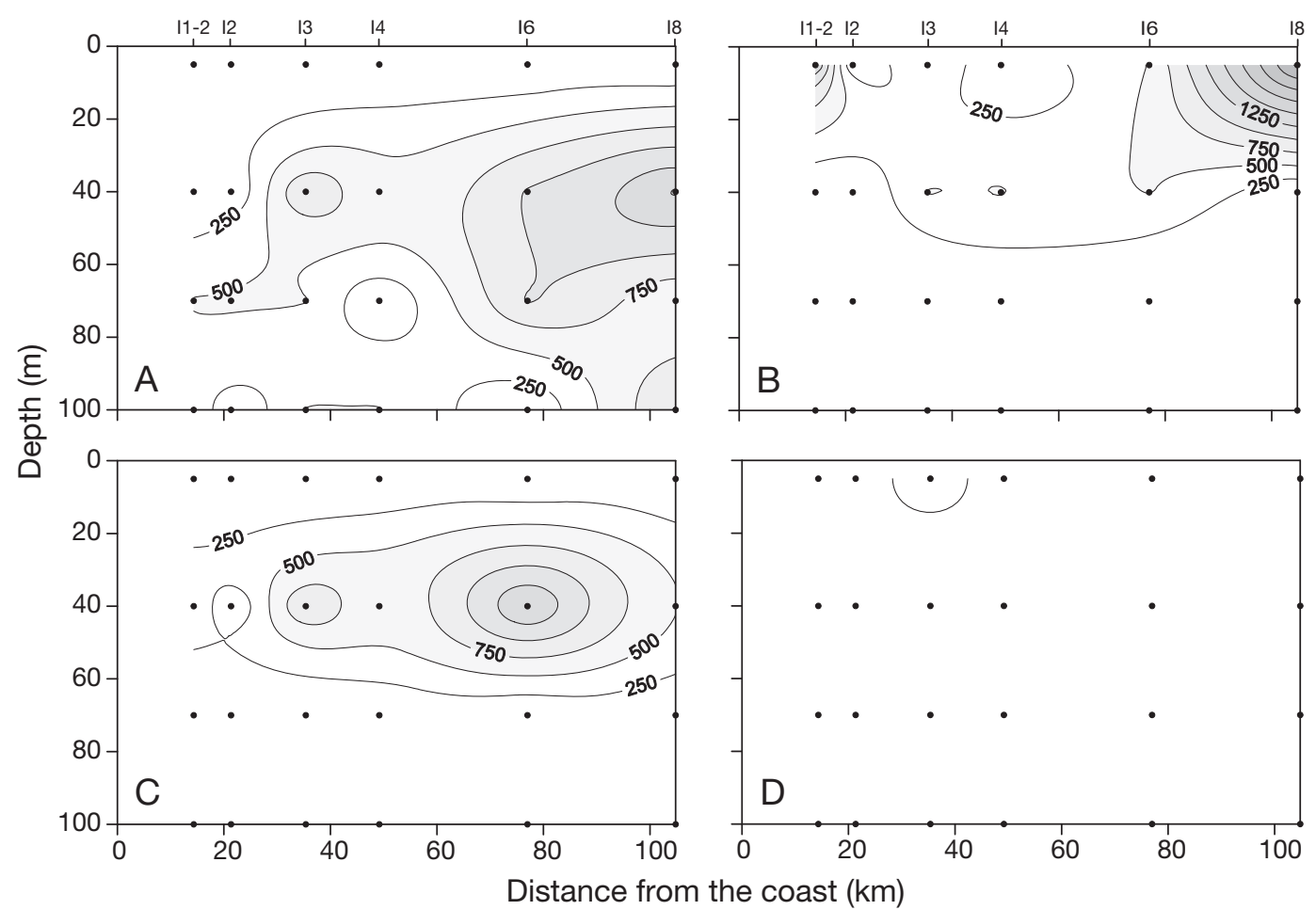

Fig. 5. Distribution of representative hetero-holococcolithophore pairs in transect I of MESO-96 cruise (values in cells $\mathrm{l}^{-1}$ ). In (A) and (B), respectively: Helicosphaera carteri HET and H. carteri HOL, formerly Syracolithus catilliferus. In (C) and (D), respectively: Syracosphaera halldalii HET and S. halldalii HOL, formerly Calyptrolithina divergens var. tuberosa 


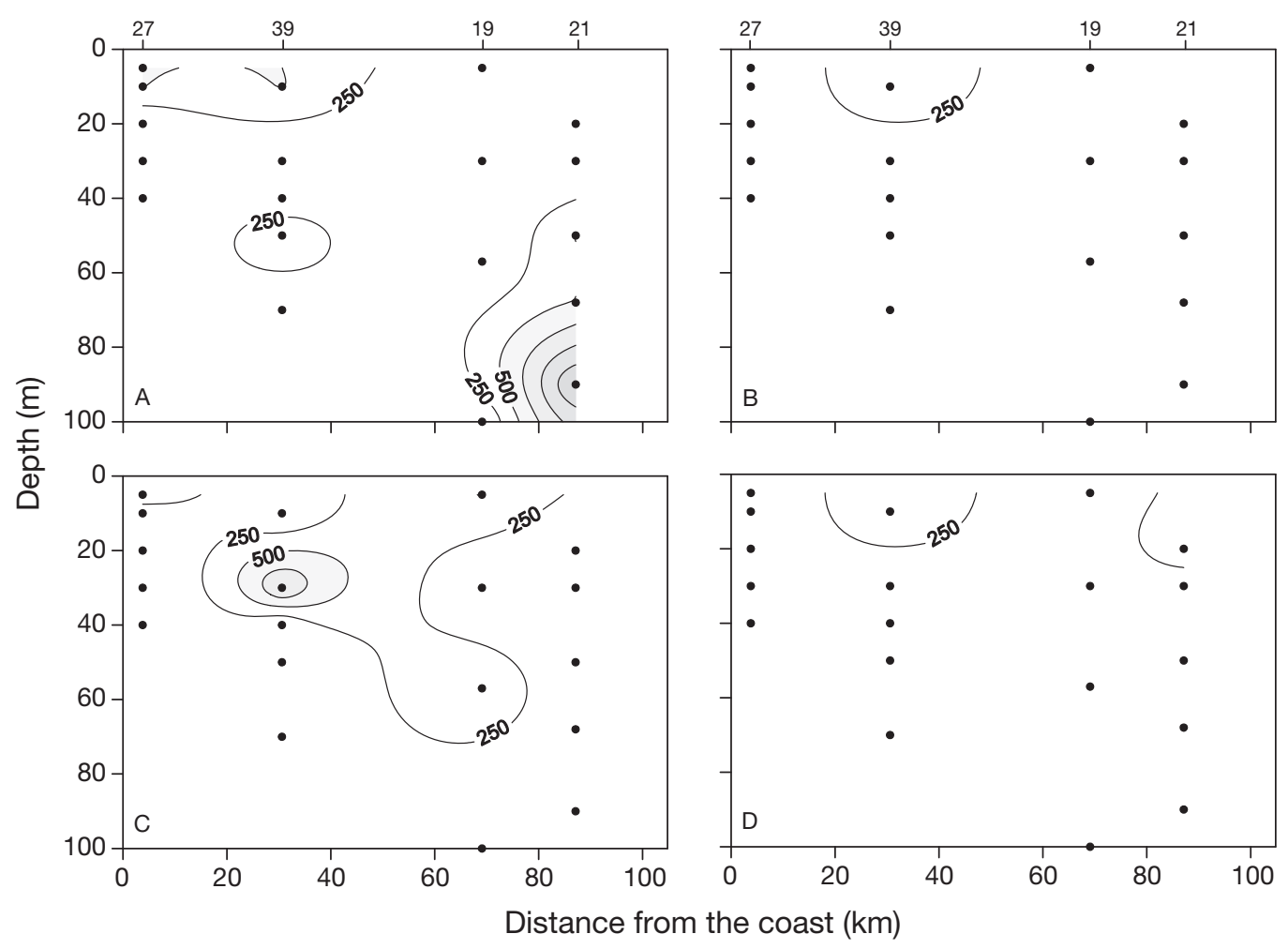

Fig. 6. Distribution of representative hetero-holococcolithophore pairs in FRONTS-96 (values in cells $1^{-1}$ ). In (A) and (B), respectively: Helicosphaera carteri HET and H. carteri HOL, formerly Syracolithus catilliferus. In (C) and (D), respectively: Coronosphaera mediterranea HET and C. mediterranea HOL, formerly Calyptrolithina wettsteinii

groups becomes more important, while diatom concentrations decrease. MESO-96 (June) and FRONTS96 (September) were carried out, respectively, about one month before and one month after the period of maximum vertical stratification, which tends to occur between late July and end of August (SeguraNoguera et al. 2011), and presented similar stratification conditions (as measured by estimations of the Brunt-Vaisälä frequency; data not shown). Both

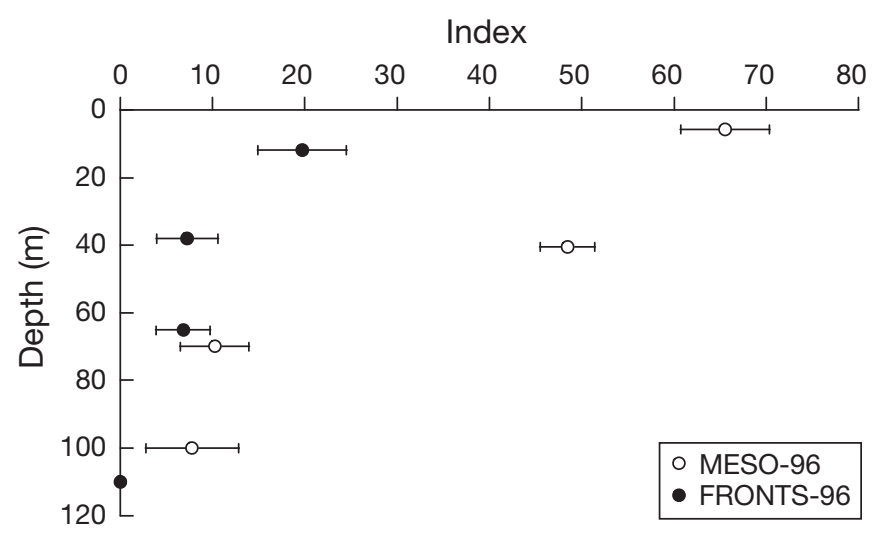

Fig. 7. Vertical distribution of the mean $( \pm$ SE) holococcolithophore prevalence index for different depth intervals in the cruises MESO-96 and FRONTS-96 cruises showed fairly similar distributions of physicochemical variables, but the deep chlorophyll maximum, a typical feature of the stratification period, was more intense (Figs. 2 \& 3) in MESO-96 (June and July) than in FRONTS-96 (September). Holococcolithophores presented higher population densities and deeper distributions in June than in September (Figs. 2 to 6). In addition, in June and July, the coccolithophore diversity was higher and the dominance of Emiliania huxleyi and Gephyrocapsa ericsonii lower than in September (Tables $2 \& 3$ ). These differences could indicate a relatively higher nutrient availability in September, probably related to the incipient weakening of the pycnocline. Our findings agree with those of Dimiza et al. (2008b), who reported a higher diversity of holococcolithophores in the Aegean Sea during the more oligotrophic summer period. A temporal change between the relative abundance of the motile (holococcolithophore) and non-motile (heterococcolithophore) phases of Coccolithus pelagicus, with a high contribution of the motile form preceding that of the non-motile one had been noted by Okada \& McIntyre (1979), who also found that population peaks of E. huxleyi occurred at different times of the year than those of both stages of C. pelagicus. 
The distribution of life-cycle stages and the HOLP index indicate a prevalence of the holococcolithophore phase in shallow layers and a preferential location of the heterococcolithophore phase in deeper waters (Figs. 2 to 7 ), in combination with temporal changes in the occurrence of the 2 phases. This segregation could be linked to a differentiation of ecological niches, with the haploid holococcolithophores inhabiting the more oligotrophic surface layers and the diploid heterococcolithophores occupying relatively richer waters below the mixed layer. This interpretation is supported by the experimental work of Houdan et al. (2006), who considered the conceptual model of Margalef (1978) and proposed that the diploid heterococcolithophores and the haploid holococcolithophores might be exploiting a range of trophic environmental situations, with ecological niches closer to those of diatoms for heterococcolithophores and to those of dinoflagellates for holococcolithophores. A holococcolithophore strategy of inhabiting the oligotrophic surface waters would agree with the 'nutrient scarcity' hypothesis of Lewis (1985), who concluded that factors favouring small cell size, such as low nutrient availability, should favour haploidy in single-celled organisms (in which lower DNA content is often associated with smaller cell sizes than those of the diploid stage). Although in general the examined holo-heterococcolithophore pairs did not present a substantially different cell size (Cros 2002, Cros \& Fortuño 2002, Young et al. 2003), it could still be argued that DNA replication requires more nutrients (such as P or N) per cell for diploid than for haploid cells. Another factor that could help to explain the niche separation is the existence of mixotrophy in the haploid stage, as shown for Coccolithus braarudii HOL, which could supplement its diet by preying on small bacteria (Houdan et al. 2006). This ability could help holococcolithophores to supplement their diets in the nutrient-poor shallower waters. Whereas 'nutrient scarcity' and related hypotheses could provide an explanation for holo-heterococcolithophore segregation, there might be other relevant factors, such as UV radiation. Quintero-Torres et al. (2006) used a dipolar multiscattering model to conclude that the crystalline photonic structure of certain holococcoliths enhanced UV backscattering and suggested that this property could represent an advantage for these holococcolithophores, by improving their ability to live higher in the water column than other coccolithophores.

The ecological differentiation between haploid and diploid phases in coccolithophores could also have ecological implications for taxa from non-HHLC families, such as the ubiquitous Emiliania huxleyi. The life cycle of this coccolithophore comprises a diploid, non-motile, coccolith-bearing phase, able to form extensive blooms, and a haploid flagellated phase with a cell covering of non-mineralized organic scales, which is difficult to recognize by standard microscopical methods and has been mostly overlooked. While E. huxleyi blooms are often terminated by viral infection, the haploid phase of E. huxleyi appears to be resistant to the viruses that kill the diploid phase (Frada et al. 2008). These authors show also that viral exposure may induce transition from the diploid to the haploid phase and conclude that this 'Cheshire cat' escape strategy releases host evolution from pathogen pressure. The mechanisms underlying the resistance of haploid E. huxleyi could include a protective effect of the organic scale covering or the absence of molecules recognized by the viruses (Frada et al. 2008), but there is no conclusive evidence and it is not known whether viral infection could have a relationship with life stage transitions in coccolithophores with calcified haploid phases. Rokitta et al. (2011) found that the haploid and diploid life-cycle stages of $E$. huxleyi presented different gene expression patterns and that both haploid and diploid individuals of E. huxleyi in late stationary culture stage could engulf particles of $0.5 \mu \mathrm{m}$ diameter by phagocytosis. According to these authors, the smaller genome and more basic transcriptome of the haploid stage could minimize cellular energetic and material needs (Rokitta et al. 2011). Surveys of calcified (diploid) and non-calcified (haploid) cells of $E$. huxleyi using molecular techniques suggested a scenario in which both life stages coexisted in the same water body, following parallel population dynamics (Frada et al. 2012), with calcified cells representing the most abundant phase and non-calcified cells increasing their contribution at specific time windows, such as the end of the exponential phase, coinciding with bursts of E. huxleyi viruses. Thus, the different morphology and marked physiological differentiation among haploid and diploid stages strongly strengthens the view that diploid and haploid cells may exploit different spatio-temporal niches, displaying distinct roles in nature (Rokitta et al. 2011, Frada et al. 2012). The scarcity of data on the distribution of the haploid phase of E. huxleyi hinders the consideration of other ecological aspects of life stage differentiation in this species; however, this situation could improve soon with the implementation of molecular techniques (Frada et al. 2006).

The preference of holococcolithophores for shallower levels of the water column than those occupied 
by heterococcolithophores (Fig. 7), which may be related to drivers such as gradients in nutrient availability or UV irradiance, can be seen as a strategy for a more efficient exploitation of available ecological niches (Valero et al. 1992, Hughes \& Otto 1999). Further research on the biphasic life cycle of coccolithophores, in particular regarding the distribution of the holococcolithophore stage, would help not only to understand the population dynamics of these biogeochemically important organisms, but would also provide insight into the general significance of haploiddiploid life cycle strategies.

Acknowledgements. We thank J. Salat for providing unpublished physico-chemical data and the teams of MESO-96 and FRONTS-96 for sample collection and chlorophyll analyses. We are very grateful to J.-M. Fortuño for assistance with the scanning electron microscope and to L. Arin for help with the figures. This research was supported by the CSIC, the Grup de Recerca Consolidat 2009 SGR 588 of the Generalitat of Catalonia and the projects AMB94-083 (CICYT) and CODENET (FRMX-ET97-0113).

\section{LITERATURE CITED}

Balch WM, Holligan PM, Kilpatrick KA (1992) Calcification, photosynthesis and growth of the bloom forming coccolithophore Emiliania huxleyi. Cont Shelf Res 12: 1353-1374

Balestra B, Ziveri P, Monechi S, Troelstra S (2004) Coccolithophorids from the Southeast Greenland Margin (Northern North Atlantic): production, ecology and the surface sediment record. Micropaleontology 50(Suppl 1): 23-34

Billard C (1994) Life cycles. In: Green JC, Leadbeater BSC (eds) The haptophyte algae. Systematics Association Spec Vol 51. Clarendon Press, Oxford, p 167-186

Billard C, Inouye I (2004) What is new in coccolithophore biology? In: Thierstein HR, Young JR (eds) Coccolithophores: from molecular processes to global impact. Springer, Berlin, p 1-29

Brand LE (1994) Physiological ecology of marine coccolithophores. In: Winter A, Siesser WG (eds) Coccolithophores. Cambridge University Press, Cambridge, p 39-49

Cachao M, Moita MT (2000) Coccolithus pelagicus, a productivity proxy related to moderate fronts off Western Iberia. Mar Micropaleontol 39, Spec Issue: Nannoplankton Ecology and Palaeoecology: 131-155

> Cortés MY, Bollman J (2002) A new combination of the heterococcolith species Coronosphaera mediterranea and the holococcolith species Calyptrolithophora hasleana. Eur J Phycol 37:145-146

Cros L (2002) Planktonic coccolithophores of the NW Mediterranean. PhD thesis (2001) at University of Barcelona. Publicacions de la Universitat de Barcelona

Cros L, Fortuño JM (2002) Atlas of northwestern Mediterranean coccolithophores. Sci Mar 66 (Suppl 1):7-182

Cros L, Kleijne A, Zeltner A, Billard C, Young JR (2000) New examples of holococcolith-heterococcolith combination coccospheres and their implications for cocolithophorid biology. Mar Micropaleontol 39:1-34

D'Ortenzio F, Ribera d'Alcala M (2009) On the trophic regimes of the Mediterranean Sea: a satellite analysis. Biogeosciences 6:139-148

Dimiza MD, Triantaphyllou MV, Dermitzakis MD (2008a) Vertical distribution and ecology of living coccolithophores in the marine ecosystems of Andros Island (Middle Aegean Sea) during late summer 2001. Hell J Geosci 43:7-20

Dimiza MD, Triantaphyllou MV, Dermitzakis MD (2008b) Seasonality and ecology of living coccolithophores in eastern Mediterranean coastal environments (Andros Island, Middle Aegean Sea). Micropaleontology 54: 159-175

Estrada M, Varela RA, Salat J, Cruzado A, Arias E (1999) Spatio-temporal variability of the winter phytoplankton distribution across the Catalan and North Balearic fronts (NW Mediterranean). J Plankton Res 21:1-20

> Frada M, Not F, Probert I, de Vargas C (2006) $\mathrm{CaCO}_{3}$ optical detection with fluorescent in situ hybridization: a new method to identify and quantify calcifying microorganisms from the oceans. J Phycol 42:1162-1168

Frada M, Probert I, Allen MJ, Wilson WH, de Vargas C (2008) The 'Cheshire Cat' escape strategy of the coccolithophore Emiliania huxleyi in response to viral infection. Proc Natl Acad Sci USA 105:15944-15949

> Frada M, Percopo I, Young J, Zingone A, de Vargas C, Probert I (2009) First observations of heterococcolithophore-holococcolithophore life cycle combinations in the family Pontosphaeraceae (Calcihaptophycideae, Haptophyta). Mar Micropaleontol 71:20-27

> Frada MJ, Bidle KD, Probert I, de Vargas C (2012) In situ survey of life cycle phases of the coccolithophore Emiliania huxleyi (Haptophyta). Environ Microbiol 14: 1558-1569

Fresnel J (1989) Les coccolithophorides (Prymnesiophyceae) du littoral: Genres: Cricosphaera, Pleurochrysis, Cruciplacolithus, Hymenomonas et Ochrosphaera. Ultrastructure, cycle biologique, systématique. Thèse de Doctorat d'Etat (Sciences), Université de Caen

- Fresnel J (1994) A heteromorphic life cycle in two coastal coccolithophorids, Hymenomonas lacuna and Hymenomonas coronata (Prymnesiophyceae). Can J Bot 72: 1455-1462

- Fresnel J, Billard C (1991) Pleurochrysis placolithoides sp. nov. (Prymnesiophyceae), a new marine coccolithophorid with remarks of the status of cricolith-bearing species. Br Phycol J 26:67-80

Gayral P, Fresnel J (1983) Description, sexualité et cycle de développement d'une nouvelle Coccolithophoracée (Prymnesiophyceae): Pleurochrysis pseudoroscoffensis sp. nov. Protistologica 19:245-261

Geisen M, Billard C, Broerse ATC, Cros L, Probert I, Young JR (2002) Life-cycle associations involving pairs of holococcolithophorid species: intraspecific variation or cryptic speciation? Eur J Phycol 37:531-550

Geisen M, Young JR, Probert I, Sáez AG and others (2004) Species level variation in coccolithophores. In: Thierstein HR, Young JR (eds) Coccolithophores: from molecular processes to global impact. Springer, Berlin, p 327-366

Houdan A, Billard C, Marie D, Not F, Sáez AG, Young JR, Probert I (2004) Holococcolithophore-heterococcolithophore (Haptophyta) life cycles: flow cytometric analysis of relative ploidy levels. Syst Biodivers 1:453-465 
Houdan A, Probert I, Zatylny C, Véron B, Billard C (2006) Ecology of oceanic coccolithophores. I. Nutritional preferences of the two stages in the life cycle of Coccolithus braarudii and Calcidiscus leptoporus. Aquat Microb Ecol 44:291-301

Hughes JS, Otto SP (1999) Ecology and the evolution of biphasic life cycles. Am Nat 154:306-320

Kleijne A (1993) Morphology, taxonomy and distribution of extant coccolithophorids (Calcareous nannoplankton). PhD thesis. Vrije University, Amsterdam. FEBO, Enschede

Lewis WM Jr (1985) Nutrient scarcity as an evolutionary cause of haploidy. Am Nat 125:692-701

Manton I, Leedale GF (1969) Observations on the microanatomy of Cocccolithus pelagicus and Cricosphaera carterae with special reference to the origin and nature of coccoliths and scales. J Mar Biol Assoc UK 49:1-16

Margalef R (1978) Life-forms of phytoplankton as survival alternatives in an unstable environment. Oceanol Acta 1: 493-509

Noël MH, Kawachi M, Inouye I (2004) Induced dimorphic life cycle of a coccolithophorid Calyptrosphaera sphaeroidea (Prymnesiophyceae, Haptophyta). J Phycol 40: $112-129$

Okada H, McIntyre A (1979) Seasonal distribution of modern coccolithophores in the western north Atlantic Ocean. Mar Biol 54:319-328

Parke M, Adams I (1960) The motile (Crystallolithus hyalinus Gaarder and Markali) and nonmotile phases in the life history of Coccolithus pelagicus (Wallich) Schiller. J Mar Biol Assoc UK 39:263-274

Quintero-Torres R, Aragón L, Torres M, Estrada M, Cros L (2006) Strong far-field coherent scattering of ultraviolet radiation by holococcolithophores. Phys Rev E 74: 032901, doi:10.1103/PhysRevE.74.032901

Rayns DG (1962) Alternation of generations in a coccolithophorid, Cricosphaera carterae (Braarud and Fagerl.) Braarud. J Mar Biol Assoc UK 42:481-484

Rokitta SD, de Nooijer LJ, Trimborn S, de Vargas C, Rost B, John U (2011) Transcriptome analyses reveal differential gene expression patterns between the life-cycle stages of Emiliania huxleyi (Haptophyta) and reflect specialization to different ecological niches. J Phycol 47:829-838

Rost B, Riebesell U (2004) Coccolithophores and the biological pump: responses to environmental changes. In: Thierstein HR, Young JR (eds) Coccolithophores: from molecular processes to global impact. Springer, Berlin, p 99-125

Rowson JD, Leadbeater BSC, Green JC (1986) Calcium car-

Editorial responsibility: Graham Savidge,

Portaferry, UK bonate deposition in the motile (Crystallolithus) phase of Coccolithus pelagicus (Prymnesiophyceae). Br Phycol J 21:359-370

Saez AG, Probert I, Geisen M, Quinn P, Young JR, Medlin LK (2003) Pseudo-cryptic speciation in coccolithophores. Proc Natl Acad Sci USA 100:7163-7168

> Segura-Noguera M, Cruzado A, Blasco D (2011) Nutrient preservation, analysis precision and quality control of an oceanographic database of inorganic nutrients, dissolved oxygen and chlorophyll a from the NW Mediterranean Sea. Sci Mar 75:321-339

> Thomsen HA, Østergaard JB, Hansen LE (1991) Heteromorphic life histories in Arctic coccolithophorids (Prymnesio- phyceae). J Phycol 27:634-642

> Triantaphyllou MV, Dimiza MD (2003) Verification of the Algirosphaera robusta-Sphaerocalyptra quadridentata (coccolithophores) life-cycle association. J Micropaleontol 22:107-111

Triantaphyllou MV, Dermitzakis MD, Dimiza MD (2002) Holo- and Heterococcolithophores (calcareous nannoplankton) in the gulf of Korthi (Andros Island, Aegean Sea, Greece) during late summer 2001. Revue Paléobiol. Genève. 21: 353-369

Triantaphyllou MV, Dimiza MD, Dermitzakis MD (2004) Syracosphaera halldalii and Calyptrolithina divergens var. tuberosa life-cycle association and relevant taxonomic remarks. In: Triantaphyllou MV (ed) Advances in the biology, ecology and taphonomy of extant calcareous nannoplankton. Micropaleontology 50 Suppl 1: 121-126

> Valero M, Richerd S, Perrot V, Destombe C (1992) Evolution of alternation of haploid and diploid phases in life cycles. Trends Ecol Evol 7:25-29

Westbroek P, van Hinte JE, Brummer GJ, Veldhuis M and others (1994) Emiliania huxleyi as a key to biospheregeosphere interactions. In: Green JC, Leadbeater BSC (eds) The haptophyte algae. Systematics Association Spec Vol 51. Clarendon Press, Oxford, p 321- 334

> Yentsch CS, Menzel DW (1963) A method for the determination of phytoplankton chlorophyll and phaeophytin by fluorescence. Deep-Sea Res Oceanogr Abstr 10:221-231

Young JR (1994) Function of coccoliths. In: Winter A, Siesser WG (eds) Coccolithophores. Cambridge University Press, Cambridge, p 63-82

Young JR, Davis SA, Bown PR, Mann S (1999) Coccolith ultrastructure and biomineralisation. J Struct Biol 126: 195-215

Young JR, Geisen M, Cros L, Kleijne A, Sprengel C, Probert I, Østergaard J (2003) A guide to extant coccolithophore taxonomy. J Nannoplankton Res 1(Spec Issue):1-132

Submitted: January 18, 2013; Accepted: July 6, 2013 Proofs received from author(s): October 11, 2013 